\title{
The Analysis Effect of Brand Identity and Brand Image toward Brand Satisfaction and Brand Loyalty of Chocolate Product in Samarinda
}

\author{
Suminto $^{1^{*}}$, Indah Martati ${ }^{2}$, Dyah Kusrihandayani ${ }^{3}$, Erika Estiyani ${ }^{4}$
}

${ }^{1}$ Business Administration Department, Samarinda State Polytechnic,75124, Indonesia ${ }^{2}$ Business Administration Department, Samarinda State Polytechnic,75124, Indonesia ${ }^{3}$ Business Administration Department, Samarinda State Polytechnic,75124, Indonesia ${ }^{4}$ Business Administration Department, Samarinda State Polytechnic,75124, Indonesia

Email: suminto@polnes.ac.id

\section{ABSTRACT}

This study aims to analyze the effect of brand identity and brand image on brand satisfaction and brand loyalty of silverqueen chocolate products in Samarinda City. A quantitative approach using path analysis processed with IBM SPSS 23 software and Structural Equation Modeling (SEM) with IBM AMOS 5 software. A total of 132 respondents who had consumed Silverqueen chocolate in Samarinda were the samples in this study. The measurement scale uses a Likert scale with a score of $1-5$. In the beginning, validity and reliability tests are carried out on the research instrument, then estimation tests and structural model fit tests are conducted. The results showed that brand identity and brand image had a significant effect on brand satisfaction and had no significant effect on brand loyalty. Likewise, brand satisfaction has no significant effect on brand loyalty. The results of this study state that brand variables that affect brand satisfaction will not automatically encourage brand loyalty.

\section{ARTICLE HISTORY}

Submitted:23.11.2021

Revised:20.12.2021

Accepted:04.01.2022

Online first:05.01.2022

\section{KEYWORDS}

Brand Identity;

Brand Image;

Brand Satisfaction;

Brand Loyalty 


\section{Introduction}

Snacks are foods that are consumed as an interlude between main meals. Damaledo (2019), the results in the State of Snacking survey released in December 2019 analyzes consumer snacking habits, insights, and trends in Indonesia and 11 other countries in the world. The results of the analysis, Indonesian people consume snacks more often than heavy meals. One of the snacks that have an effect on making the mood very good and suitable to accompany as a snack when relaxing or bored, one of which is chocolate. Yolanda (2020) is one of the famous brand chocolates from Indonesia, namely Silverqueen brand chocolate. In the last five years, namely the 2016-2020 period, Silverqueen is successively the top brand index in Indonesia for the chocolate bar category, followed by the Codbury, Delfy, Toblerone brands. The recognition of the Silverqueen brand is allegedly related to brand identity, brand image, brand satisfaction and brand loyalty.

Referring to the research of Dehdashti et al. (2012) proved that brand identity has a significant positive effect on loyalty, while the research of Fariza et al. (2018) found that brand identity does not significantly affect brand loyalty. Cha \& Seo's research (2019) shows that brand image has a significant positive effect on brand satisfaction, while the results of Chakraborty's (2019) research show the opposite. The inconsistency of the results of the previous research shows that there is still a research gap. Therefore, researchers are interested in examining the effect of brand identity and brand image on brand satisfaction and brand loyalty on Silverqueen chocolate products in Samarinda City.

The purpose of this study is to analyze and prove: 1) the influence of brand identity and brand image on brand satisfaction and brand loyalty on Silverqueen chocolate products in Samarinda City. Meanwhile, the problems are: 1) Do brand identity and brand image have a significant effect on brand satisfaction, 2) Do brand identity and brand image have a significant effect on brand loyalty?. 3) Does brand satisfaction have a significant effect on brand loyalty on Silverqueen chocolate products in Samarinda City?

\section{Research Method}

\subsection{Sample, population and data collection techniques}

The method used in this study is a survey method by giving questionnaires to respondents who happened to be met at random. The questionnaire used is a Likert scale of 1 -5 with criteria $1=$ strongly disagree and $5=$ strongly agree with a sample of 132 community respondents who live in Samarinda as the population. The data were then analyzed through several statistical assumption tests, this was done as a material to draw a research conclusion on the relationship between the observed research variables.

\subsection{Research variable indicators}

There are 19 indicators in this study derived from exogenous, intervening and endogenous variables, with the following details: indicators for the brand identity variable are 4, namely far from rival, high class and high quality brand, popular brand and Distinguished brand adopted from adoption. from Bhattacharya \& Sen (2003). The brand image variable has 4 indicators, namely friendly modern, useful, popular, gentle, which was adopted from Mabkhot et al. (2017). Meanwhile, there are 4 indicators for the brand satisfaction variable, which were adopted from Liembawati et al. (2014), which include satisfied with product quality, price comparable, happy with brand, right decision. Meanwhile,there are 5 indicators 
in the brand loyalty variable that the authors adopted from Rodrigues, P \& Reis (2013) Loureiro et al. (2012) in the journal Andriani \& Dwbunga (2018), namely first choice, faithful, repurchase, recommend, and word of mouth.

\subsection{Testing}

\section{1). validity and reliability test}

The first step is to test the validity and reliability of the instruments, SPSS version 23 software is used. The results of acceptance of the validity and reliability tests, according to Sugiyono (2012) are based on the value of each correlation coefficient $<0.30$ and Cronbach alpha 0.60 . Several tests are also carried out to obtain results in accordance with the research model. The classical assumption test is an analysis carried out to assess whether in an Ordinary Least Square OLS) linear regression model, there are classical assumption problems, as follows:

\section{2).Linearity, Normality and Multicollinearity Test}

According to Narmiwati (2008) multiple linear regression is an association analysis that is used simultaneously to examine the effect of two or more independent variables on one dependent variable on an interval scale. The relationship is said to be linear if it is significant $<0.50$. For sample data that is normally distributed, parametric statistical techniques can be used (Product Moment/Pearson Regression). Normality test can use the One Sample Kolmogrov-Smirnov test using a significant level of 0.05 , the data is declared normally distributed if the significance is greater than $5 \%$ or 0.05 . Multicollinearity test used to determine the linear relationship between exogenous in the regression model. If multicolline occurs, the position of the variable as an exogenous variable cannot be accounted for statistically. According to Ghozali, 2016 a good regression model is that there is no correlation between the independent variables. The way to know multicollinearity is to look at the value of Variance Infiation Factors (VIF). With VIF can be compared the value of the coefficient of individual determination ( $\mathrm{r} 2$ ) with the value of the coefficient of determination ( $\mathrm{r} 2$ ) simultaneously. If the coefficient of VIF $<5$, then the exogenous variable is free from multicollinearity problems.

\subsection{Data Analysis Techniques}

In this study, Structural Equation Modeling (SEM) from the AMOS statistical software package was used in model development and hypothesis testing. This study uses two kinds of analytical techniques, namely: Confirmating Factor Analysis or confirmatory factor analysis in SEM is used to confirm the most dominant factors in a group of variables, Regression Weight on SEM is used to examine how much the research variables influence each other . Evaluation of the criteria for the goodness of fit is an evaluation of the feasibility test of a model with several criteria for suitability of the index and cutting its value, in order to approve whether a model can be accepted or rejected. The absolute goodness criteria used are 1) ChiSquare, which is to measure the difference between the sample covariance matrices; 2) Significance of Probability, namely which is used to convey the level of significance of the model; 3) CMIN / DF ratio, which is suitable for measuring obtained from Chi-square value divided by degrees of freedom; 4) GFI (goodness of fit index) consists of non-statistical measures judged from 0 (bad fit) to 1.0 (perfect fit) and GFI above $90 \%$ as a measure of fit; 5) RMSEA (Root Mean Square Error of Approximation) is to correct the tendency of Chi-Square 
values to reject models with large samples. Values received range from 0.05 to 0.08 ; and added with incremental goodness of fit, 6) AGFI (Adjusted Goodness of Fit) is used to determine between the proposed model, the basic model, or the zero model, and the level of acceptance is $0.90 ; 7)$ TLI (Tucker Lewis Index) is a measuring tool with parsimony measurement into the comparative index between the proposed model and the zero model, and the level of acceptance is $0.90 ; 8$ ) CFI (Comparative Fit Index), which is an incremental conformity index that is suitable because it is relatively insensitive to increasing sample and is less used by the complexity of the model. The value of acceptance is $>0.90$ (Ghozali \& Fuad, 2008)

\section{Research result and Discussion}

Hasil The results of testing the validity and reliability of 30 pilot test questionnaires from 19 indicators from 4 variables, namely (X1) brand identity (X2) brand image (Y1) brand satisfaction and (Y2) brand loyalty in this study are declared valid because each item has a value. Pearson correlation is more than 0.30 and is declared reliable because Croanbach's alpha is more than 0.60 .

The results of the linearity test stated that all the relationships between the independent variables and the dependent variable in the study had a linear relationship because they had met the requirements, namely the linearity value $(0.000)<0.05$. For the normality test using the One Sample Kolmogorov-Smirnov test, the results of Sig. $>$ from 0.1. The value of the coefficient of inflation factor (VIF) for brand identity and brand image is 1.34, where this value shows $<5$ meaning that there is no multicollinearity between exogenous variables. The results of the goodness of fit model are compared to its cut off value which is used to test whether a model can be accepted or rejected, as shown in Table 1.

Table 1.

Overall Model Goodness of Fit Index Test Results

\begin{tabular}{|c|c|c|c|}
\hline Goodness of Fit index & Cut of Value & Model Result & Remark \\
\hline Chi-square & small & 232.180 & Not Fit \\
\hline Significancy Probability & $\geq 0,05$ & 0.059 & Good Fit \\
\hline $\mathrm{CMIN} / \mathrm{DF}$ & $\leq 2,00$ & 1.161 & Good Fit \\
\hline RMR & $\leq 0,08$ & 0.068 & Good Fit \\
\hline GFI & $\geq 0,90$ & 0.873 & Not Fit \\
\hline AGFI & $\geq 0,90$ & 0.840 & Not Fit \\
\hline TLI & $\geq 0,95$ & 0.968 & Good Fit \\
\hline CFI & $\geq 0,95$ & 0.972 & Good Fit \\
\hline RMSEA & $\leq 0,08$ & 0.035 & Goof Fit \\
\hline
\end{tabular}

Source: Data has been processed by researchers, 2021

Based on Table 1. Above, it shows that the results of the goodness of fit index test that meet the cut of value are Chi-square, Significancy Probability, RMR, RMSEA, CMIN/DF, TLI, and CFI with the values listed in the table, the research model in this study can be declared fit, meaning that the research model is feasible to use.The results of hypothesis testing with the help of AMOS version 5 software are as listed in Table 2. 
Hypothesis Testing Results

\begin{tabular}{ccccc}
\hline Variable & $\begin{array}{c}\text { Standardized } \\
\text { Path } \\
\text { Coefficient }\end{array}$ & $\begin{array}{c}\text { C.R } \\
\text { (Critical Ratio) }\end{array}$ & Probability & Remark \\
\hline BI $\rightarrow$ BS & 0.452 & 4.414 & 0.000 & Signifikant \\
BIMG $\rightarrow$ BS & 0.696 & 6.042 & 0.000 & Signifikant \\
BI $\rightarrow$ BL & 0.048 & 0.308 & 0.758 & Not Signifikan \\
BIMG $\rightarrow$ BL & 0.273 & 1.226 & 0.220 & Not Signifikan \\
BS $\rightarrow$ BL & 0.067 & 0.327 & 0.744 & Not Signifikan \\
\hline
\end{tabular}

Source: Data has been processed by researchers, 2021

Table 2 shows that of the 3 hypotheses proposed, H1 is accepted, which is proven that brand identity and brand image have a significant effect on brand satisfaction. The Critical Ratio (C.R) value is 4.414 with a probability number of $0.000\left(^{* * *}\right)$. This value meets the requirements for the acceptance of the second hypothesis, it can be stated that the hypothesis is proven. The results of the calculation of the parameter coefficients between brand identity and brand satisfaction show a positive direction with a value of 0.452 or the level of close relationship between brand identity variables and brand satisfaction is $45 \%$.

The strongest indicator of the brand identity variable is the distinguished brand indicator with a loading factor value of 0.736 , which is greater than the error term, which is 0.3. The variable that is affected, namely brand satisfaction has a happy with brand indicator as a reflection of the brand satisfaction variable, has the largest loading factor value than the other indicators, which is 0.774 , which is greater than the error term value, which is 0.3 . This means that the brand identity is seen in the well-known brand owned by Silverqueen chocolate, resulting in consumers in the city of Samarinda being more satisfied with the Silverqueen chocolate brand.

The p-value or probability value between the brand image variable and the brand satisfaction variable is $0.000\left(^{* * *}\right)$ which means it is smaller than the specified error rate of 0.050 . Or the Critical Ratio (C.R.) value is greater than 1.96 determined from the $t$ table if the research data uses more than 100 respondents. The Critical Ratio (C.R.) in this relationship is 6.042, which means the C.R. greater than the critical value of 1.96. This shows that the brand image variable has a significant positive effect on the brand satisfaction variable.

The strongest indicator of the brand image variable is the gentle indicator with a loading factor value of 0.727 , which is greater than the error term, which is 0.3 . The variable that is influenced is the brand satisfaction variable having a happy with brand indicator which has the largest loading factor value than the other indicators, which is 0.774 , which is greater than the error term value, which is 0.3 . The brand image variable which is reflected in the gentle indicator has a significant positive effect on the brand satisfaction variable which is reflected in the happy with brand indicator. This can be seen from the Silverqueen brand image which has a distinctive taste in chocolate, which will further increase satisfaction with the Silverqueen brand, thus creating a sense of pleasure for the Silverqueen brand.

The hypothesis testing (H2) is rejected, meaning that it is not proven that brand identity and brand image have a significant effect on brand loyalty. Critical Ratio (C.R) value is 0.308 with a probability number of 0.758 . This value does not meet the requirements for the acceptance of the first hypothesis, it can be stated that the hypothesis is rejected. The brand identity variable which is reflected in the distinguished brand indicator has no significant 
positive effect on the brand loyalty variable which is reflected in the recommend indicator on the Silverqueen brand of chocolate consumers in Samarinda. This means that the brand identity perceived by consumers as seen from the well-known brand owned by Silverqueen, has little influence on someone to be loyal to Silverqueen chocolate.

The p-value or probability value on the relationship between brand image and brand loyalty is 0.220 , which means it is greater than the specified error rate, namely the respondent is 0.050 . Or the critical ratio (C.R.) value is greater than 1.96 which is determined from the $t$ table if the research data uses an amount of more than 100. The critical ratio (C.R.) in this relationship is 1.226 , which means the C.R. value. Greater than the critical value of 1.96 . This shows that the brand image variable has a positive and insignificant effect on the brand loyalty variable.

The brand image variable which is reflected in the gentle indicator has no significant positive effect on the Brand loyalty variable which is reflected in the recommend indicator on Silverqueen chocolate consumers in Samarinda City. This means that the brand image that can be seen from the distinctive taste possessed by Silverqueen, has little influence on someone to be loyal to Silverqueen chocolate. In other words, the more people feel about the brand's ingredients, the less influence they have on their loyalty to recommend Silverqueen brand chocolate to people in Samarinda.

Hypothesis testing $(\mathrm{H} 3)$ is rejected or not proven that brand satisfaction has a significant effect on brand loyalty on Silverqueen chocolate products in Samarinda City. The p-value or probability value between the Brand satisfaction variable and the brand loyalty variable is 0.744, which means it is greater than the specified error rate of 0.050. Critical Ratio (C.R.) value is greater than 1.96 determined from $t$ table if the research data uses more than 100 respondents. Critical Ratio (C.R.) in this relationship is 0.327, which means the C.R. smaller than the critical value of 1.96 . This shows that the brand satisfaction variable has a positive and insignificant effect on the brand loyalty variable.

The brand satisfaction variable which is reflected in the happy with brand indicator has no significant positive effect on the brand loyalty variable which is reflected in the recommendation indicator on Silverqueen chocolate consumers in Samarinda City. The influence of brand loyalty on consumers of Silverqueen chocolate in Samarinda is low, because being happy with the brand does not guarantee that consumers will be loyal to Silverqueen chocolate.

The magnitude of the total influence of the brand identity variable on brand loyalty through brand satisfaction is 0.319 , which is obtained from the sum of the direct influence values, which is 0.273 with an indirect influence value of 0.046 . When viewed in terms of the total effect obtained, the value of the direct influence is greater than the value of the indirect effect. This means that the loyalty of Silverqueen chocolate consumers in Samarinda is strongly influenced by how well the Silverqueen chocolate consumers in Samarinda perceive the brand image of Silverqueen.

The magnitude of the total influence of the brand image variable on brand loyalty through brand satisfaction is 0.490 which is obtained from the sum of the direct influence values of 0.273 with the indirect influence value of 0.217 . When viewed in terms of the total effect obtained, the value of the direct influence is greater than the value of the indirect effect. This means that the loyalty of Silverqueen chocolate consumers in Samarinda is strongly influenced by how well the Silverqueen chocolate consumers in Samarinda perceive the brand image of Silverqueen. This means that if the brand image of Silverqueen chocolate is seen as good, it will increase consumer loyalty to the brand. 


\section{Conclusion}

Brand identity and brand image have a significant effect on brand satisfaction, with the findings of this study showing that Silverqueen's brand identity and brand image affect consumer satisfaction with the brand.

Brand identity and brand image have no significant effect on brand loyalty, with the findings of this study showing that Silverqueen's brand identity and brand image do not affect consumer loyalty to the Silverqueen chocolate brand on Silverqueen chocolate consumers in Samarinda City. Respondents with these characteristics are still very much influenced by other unique things.

Brand satisfaction has no significant effect on brand loyalty to Silverqueen chocolate consumers in Samarinda City. This means that consumer satisfaction with Silverqueen does not affect consumer loyalty to the Silverqueen chocolate brand. Means that consumers perceive that loyalty is not so influenced. 


\section{Author's declaration}

\section{Authors' contributions and responsibilities}

Write the contribution of each author here, or mark the following column.

\section{1} The first authors made substantial contributions to the conception and design of the study.

2

The second authors took responsibility for data analysis, interpretation and discussion of results.

3

The third authors read and approved the final manuscript.

4

The fourth author collect the data

\section{Funding}

This research is funded by Samarinda State Polytechnic in 2021 budget

\section{Availability of data and materials}

$\sqrt{ }$ All data are available from the authors.

\section{Competing interests}

$\sqrt{ }$ The authors declare no competing interest.

\section{Additional information}

$\sqrt{ }$ Write additional information related to this research, if any.

\section{Acknowledgement}

We are very grateful to management of Samarinda State Polytechnic in facilitating this research therefore it can be conducted. 


\section{References}

[1] [1] Aji, A. S., \& Hararab, N. (2018). analysis of the effect of product price, product image and customer satisfaction as a mediation on brand loyality of canned fish product from abc brands. 06(01), 83-92.

[2] Bhattacharya, C. B., \& Sen, S. (2003). Consumer-company identification: A framework for understanding consumers' relationships with companies. Journal of Marketing, 67(2), 76-88. https://doi.org/10.1509/jmkg.67.2.76.18609

[3] Cha, S., \& Seo, B. (2019). The Effect of Brand Trust of Home Meal Replacement on Repurchasing in Online Shopping. Journal of Business, Economics and Environmental Studies, 9, 21-26. https://doi.org/10.13106/jbees.2019.vo19.no3.21

[4] Chakraborty, D. (2019). Factors responsible for making young urban consumers brand loyal: A study on mobile network operators. Journal of Management Development, 38(7), 616636. https://doi.org/10.1108/JMD-01-2019-0029

[5] Damaledo, D. Y. (2019). Mondelez rilis survei Indonesian snacking trend.Tirto.Id. https://tirto.id/mondelez-rilis-survei- Indonesian snacking trend.

[6] Dehdashti, Z., Kenari, M. J., \& Bakhshizadeh, A. (2012). The impact of social identity of brand on brand loyalty development Zohreh. Management Science Letters, 2, 1425-1434. https://doi.org/10.5267/j.msl.2012.03.020

[7] Dennis, C., Papagiannidis, S., Alamanos, E., \& Bourlakis, M. (2016). The role of brand attachment strength in higher education. Journal of Business Research. https://doi.org/10.1016/j.jbusres.2016.01.020

[8] Fariza, N., Rohman, F., \& Hussein, A. S. (2018). the effect of brand identity, brand image, and perceived value on loyalty with customer satisfaction as mediation variable for costumer fresh juice bintaro. Journal of Applied Management (JAM), 17, 127-132.

[9] Hosseini, S. E., Kalashi, M., Sahebkaran, M., \& Jami, A. (2017). Assessing the impact of brand equity based on fans brand loyalty. European Online Journal of Natural and Social Sciences, 6(1), 28-36.

[10] Kazemi, A. (2013). Impact of Brand Identity on Customer Loyalty and Word of Mouth Communications, Considering Mediating Role of Customer Satisfaction and Brand Commitment. International Journal of Academic Research in Economics and Management Sciences, 2(4), 1-14. https://doi.org/10.6007/IJAREMS/v2-i4/1

[11] Khan, I., Rahman, Z., \& Fatma, M. (2016). The concept of online corporate brand experience: an empirical assessment. Marketing Intelligence and Planning, 34(5), 711-730. https://doi.org/10.1108/MIP-01-2016-0007

[12] Kim, R. B., \& Chao, Y. (2019). Effects of brand experience, brand image and brand trust on brand building process. Journal of International Studies, 12, 9-21. https://doi.org/10.14254/2071-8330.2019/12-3/1

[13] Kotler, Philip \& Keller, K. (2018). Marketing Management. In Marketing-Management. https://doi.org/10.1515/9783486801125

[14] Krystallis, A., \& Chrysochou, P. (2014). The effects of service brand dimensions on brand loyalty. Journal of Retailing and Consumer Services, 21(2), 139-147. https://doi.org/10.1016/j.jretconser.2013.07.009

[15] Liembawati, Y., Dharmayanti, D., Karina, R., \& Brahmana. (2014). analisa pengaruh brand activation terhadap pembentukan brand community pada pt ism bogasari flour mills yessy. Jurnal Manajemen Pemasaran Petra, 2(1), 1-15.

[16] Mabkhot, H. A., Hasnizam, \& Salleh, S. M. (2017). The influence of brand image and brand personality on brand loyalty, mediating by brand trust: An empirical study. Jurnal 
Pengurusan, 50, 71-82.

[17] Mabkhot, H. A., Salleh, S. M. D., \& Shaari, H. (2016). The antecedents of automobile brand loyalty: Evidence from Malaysian. International Review of Management and Marketing, 6(3), 596-602.

[18] Nam, J., Ekinci, Y., \& Whyatt, G. (2011). Brand equity, brand loyalty and consumer satisfaction. Annals of Tourism Research, 38(3), 1009-1030. https://doi.org/10.1016/j.annals.2011.01.015

[19] Marist, A. I., Yulianti, L. N., \& Najib, M. (2014). The Role of Event in Building Brand Satisfaction, Trust and Loyalty of Isotonic Drink. International Journal of Marketing Studies, 6(6), 57-65. https://doi.org/10.5539/ijms.v6n6p57

[20] Morrison, S., \& Crane, F. G. (2007). Building the service brand by creating and managing an emotional brand experience. Journal of Brand Management, 14(5), 410-421. https://doi.org/10.1057/palgrave.bm.2550080

[21] Pappu, R., \& Quester, P. G. (2016). How does brand innovativeness affect brand loyalty? European Journal of Marketing, 50(1-2), 2-28. https://doi.org/10.1108/EJM-01-20140020

[22] Puska, A., Stojanovic, I., \& Berbic, S. (2018). the Impact of Chocolate Brand Image, Satisfaction, and Value on Brand Loyalty. Economy and Market Communication Review, 15(1). https://doi.org/10.7251/emc1801037p

[23] Rahmat, \& Marso. (2020). the relationship brand experience, brand image, brand satisfaction , dan brand loyalty. Jurnal Manajemen Pemasaran, 14(1), 17-24. https://doi.org/10.9744/pemasaran.14.1.17

[24] Rodrigues, P \& Reis, R. (2013). The Influence of Brand Love In Consumer Behavior. 2, 157168.

[25] Yolanda C.(2020). Silverqueen Product Popular chocolate bars from Garut.www.Goodnews from Indonesia.id.https://2020/10/11. 